\title{
THE CONCEPT OF SOLIDARITY: \\ EMERGING FROM THE THEORETICAL SHADOWS?
}

BY

\section{LAWRENCE WILDE}

The concept of solidarity was first brought to prominence within social science by Emile Durkheim when The Division of Labour in Society appeared in 1893, and it has received sporadic attention within the discipline of Sociology ever since (see Crow, 2002). However, within the discipline of Politics there has been no comparable interest, as Steinar Stjernø points out in his recent history of the concept of solidarity (Stjernø, 2004, 20). The appearance of books by Stjernø and Hauke Brunkhorst (Brunkhorst, 2005) has gone some way towards rectifying this lacuna, one which is all the more surprising given the ubiquity of the word in twentieth-century political life. "Solidarity" seems to have been confined to the realm of rhetoric while serious theoretical work has concentrated on other aspects of political association such as democracy, nationalism, community, multiculturalism, and human rights. In essence, solidarity is the feeling of reciprocal sympathy and responsibility amongst members of a group which promotes mutual support. As such it has subjective and emotional elements, and this helps to explain its conceptual neglect, for, as John Baker et al have argued, within a liberal theoretical framework, solidarity is associated with 'love' and 'friendship', essentially private matters which individuals should be left to work out for themselves (Baker et al, 2004, 28). However, there should be no justification for failing to 
give due consideration to the nature of the collective action which has helped shape institutions and policies within states, and which is now reconstituting itself in response to the challenge of globalization.

The advance of individualism poses a clear threat to the idea of solidarity, as Stjernø points out (Stjernø, 2004, 2). A serious concern about the consequences of the weakening of social bonds has drawn an energetic academic response with the emergence of communitarian thought in the United States (Etzioni, 1998 and 2004; Crow, 2002, 43-48), and also the widespread impact of Robert Putnam's social capital thesis (Putnam, 2001 and 2004; Halpern, 2005). From a European perspective, the association of social solidarity with the achievement of the welfare state (Baldwin, 1990) creates obvious problems now that the high-tax welfare state model appears to have been replaced with a low-tax 'competition state' (J essop, 2002). State-centred conceptions of democracy suggest that a weakening of collective social provision must mean a diminution of solidarity. This applies to Stjernø, who defines solidarity as the preparedness to share resources with others by personal contribution to those in struggle or in need through taxation and redistribution organised by the state' (Stjernø, 2004, 2). However, although the emphasis on preparedness to share reminds us that feelings must be acted on if the idea of solidarity is to have any substance, his insistence on one particular form of 'delivery' is problematic. The move away from the Keynesian welfare state model does not necessarily mean any lessening of preparedness to share, for the general direction of economic policy has been dictated by the neo-liberal restructuring of the world economy. Even states with the strongest solidaristic traditions have been unable to defend the old institutions (Wilde, 1994, 39-68). Voters will not vote for a high tax strategy if a consensus exists among policy-makers that it will have disastrous economic consequences, and in many cases this consensus has been so dominant that voters have not even had that option available to them. The emphasis on the state's redistributive role in creating solidarity also fails to take into account the negative potential of state provision. Reliance on the centralised, bureaucratic processes of social protection can create a dependency culture 
rather than a solidaristic one. So, the demise (or scaling back) of the welfare state should not in itself be taken as an indication of a collapse of solidarity.

There can, of course, be no doubt that neo-liberal globalisation has transformed the social relations of production everywhere. In the old industrial heartlands of Europe and North America it has swept away heavy industries, often with devastating effects on communities, and reduced the power of labour movements. However, the damage done to traditional forms of solidarity does not preclude the development of new forms. These new forms include organisations directly addressing the global issues and operating supranationally, as well as myriad local networks responding to new needs arising out of rapid and widespread social change. ${ }^{1}$ One of the important research questions is the extent to which local forms of solidarities implicitly or explicitly connect with the wider global issues. It is also important to explore the possibility that the forces of globalisation that have devastated traditional forms of solidarity may have provoked new forms which place the idea of human solidarity on an emerging agenda of global politics. The cosmopolitan ideal, first expressed in Stoic philosophy more than two thousand years ago (Heater, 2002, 26-52), may, for the first time, have a political platform.

In the next section I will contextualise the issues surrounding the idea of solidarity by looking at what has endured and what has changed since Durkheim's original contribution. I will then discuss some of the recent approaches to the concept, highlighting unresolved problems and promising areas for future exploration.

\section{SITUATI NG SOLI DARITY}

When Durkheim argued that organic solidarity was a normal development of the social interaction typical in the modern division of labour he was issuing a challenge, not only to the prevailing sociological views of Tönnies and Spencer, but also to the prevailing political views of both the conservative 
Right and the revolutionary Left. What Durkheim regarded as 'abnormalities' preventing solidarity emerging within the framework of private property, such as industrial crises and class struggle (Durkheim, 1964, 353-373), Marxists took to be inevitable features of a fundamentally antagonistic social system. The revolutionary Left emphasised class solidarity as a means to a social revolution that would abolish capitalism, only then opening the way to the social solidarity of communist society. The conservative Right, terrified by this threat, saw only authoritarian solutions to the question of social order. Nevertheless, a political movement dedicated to the advance of social solidarity erupted on to the scene shortly after the appearance of Durkheim's book, led by the Radical leader Léon Bourgeois, author of the programmatic text, Solidarité, (1896). According to Hayward the 'Solidarist' movement was so successful that solidarity became the 'official social philosophy of the Third Republic' in the period leading up to the First World War (Hayward, 1961). ${ }^{2}$ The idea was popular among social liberals who recognised that the original republican commitment to "fraternity" was not being met in a society operating on the principles of laisser-faire economics. Solidarism was an attempt to overcome class antagonisms around a programme of social progress for all, so that individualism could be reconciled with a sense of collective responsibility (Hayward, 1959, 269).

Although there were parallel movements from social liberals in other countries (Baldwin, 1990, 34-5), in France there were particular reasons why this concern should revolve around the concept of solidarity. Not only was the affinity with the republican principle of 'fraternity' important, but it reflected the original working-class use of the word in the $1840 \mathrm{~s}$ as part of a democratic demand for social inclusion through wider political and social rights (Magraw, 1992, 52; Hayward, 1959, 277). The savage suppression of the Paris Commune of 1871 drove sections of the working class in the direction of revolutionary class conflict, and in the struggle to establish the legitimacy of the Republic the Radicals sought to heal the wounds and create a new national solidarity. Solidarism as a movement achieved only limited success due to the strength of the opposition to its Right and Left, and this 
clash of solidarities was evident in the other industrialised states. On the one hand the class struggles were too pronounced for successful movements of social solidarity to emerge, but, on the other, the grip of nationalist sentiment was so strong that socialist movements readily supported the war efforts of their states in 1914.

The paradox at the heart of solidarity has long been evident. On the one hand it has connotations of unity and universality, emphasising responsibility for others and the feeling of togetherness. On the other hand it exhibits itself most forcefully in antagonism to other groups, often in ways which eschew the possibility of compromise. Yet following the period of sustained economic prosperity and full employment in the 1950s and 1960s it seemed to many from the social liberal and social democratic traditions that genuine progress towards social solidarity was being made in a consensus around the welfare state (Baldwin, 1999, 288-299; Stjernø, 2004, 251). State regulation appeared to have consigned major economic crises to history, independent pressure groups flourished as intermediaries between the citizen and the state, and the welfare state promised an end to abject deprivation all developments consistent with Durkheim's prescriptions. In addition, the development of the European Economic Community appeared to realise Durkheim's vision that 'beyond this country, there is another country in the process of formation, enveloping our national country: that of Europe, or humanity' (in Lukes, 1973, 350). Imperialism was coming to a close, and, at the global level, the 1948 Declaration of Human Rights, agreed by the United Nations, signalled a shared aspiration to universal social obligation.

However, even during the long period of prosperity which lasted until the mid-1970s it is evident that many of Durkheim's 'abnormalities' were clearly still in place in most of the economically advanced countries. Prejudices based on class, ethnicity and gender gave rise to widespread discrimination, and even within close communities the solidarity of the majority all too frequently gave rise to alienation of the minority. In countries with a strong tradition of labour solidarity, this was often accompanied by a range of exclusionary practices. In other words, all that was "solid" was not 
necessarily harmonious or fair. Nevertheless there was a tremendous social cost to pay when those established social bonds were devastated as a result of the economic restructuring which followed the end of the post-war boom, particularly in the creation of the 'new poor' (Bauman, 2001, 72-80). Looking beyond the affluent states to the world economy, the processes of restructuring, governed by the WTO/IMF/World Bank elites, have left the poorest even poorer. Solidarities based on occupation, community and traditional culture have been severely tested during this period, but these changes have also provoked a new questioning about the social consequences of unfettered competition. The rise of new social movements has opened the possibility of new forms of solidarity through the democratization of everyday life' (Melucci, 1989, 165-179), which may lead on to 'bigger' questions about the values and goals of the social system as a whole (Melucci, 1996, 22-41). Solidarity develops in struggles against systematic discrimination on a variety of grounds, in ecological movements extending solidarity to future generations, and in movements dedicated to the welfare of other life-forms. In response to the neo-liberal governance of the world economy new movements have coalesced, sometimes in long-term umbrella movements like the Social Forums, at other times in short-lived but influential campaigns like Make Poverty History. An extensive research agenda suggests itself, with the tasks of assessing the strengths and endurance of these new solidarities, their ability to articulate with each other and with older movements, and their impact on democratic renewal, public discourse, and social policy. At the global level, the normative goal of human solidarity is raised.

\section{CONTEMPORARY PERSPECTI VES}

Just as the Solidarist movement in France was a response to deep divisions in a republic that had failed to realise its foundational aspirations to liberty, equality and fraternity, now, at the beginning of a new century, the call for 
solidarity on a global scale is a response to a deeply divided world which has failed to realise the promise of the United Nation Declaration of Human Rights. Brunkhorst sees a progressive development from the first struggles to establish modern human rights at the national level in the French and American Revolutions to the demand for the establishment of the democratic constitutional principle on a global scale. He argues that the modern conception of democracy is the heir of two traditions, the Judeo-Christian idea of brotherly solidarity and the Greco-Roman idea of civic solidarity (Brunkhorst, 2005, 55), and that democratic constitutionalism helped to overcome what he terms the 'dual inclusion' problem. The development of individualisation appears to exclude social communication, but democracy solves this problem and makes solidarity egalitarian through its inclusive guarantee of basic rights. In this way individual inclusion is won, but social inclusion is threatened by the huge disparities in power flowing from the market system; again this problem is resolved through the exercise of popular sovereignty in producing the welfare state (Brunkhorst, 2005, 81-101). Although these achievements are threatened by neo-liberalism, the struggle towards the extension of democratic power in the global sphere permits us to glimpse a trajectory towards global community. The goal of the struggle is the completion of the constitutional project of 1789, 'the selfconstitutionalisation of democratic solidarity' (Brunkhorst, 2005, 162). For Brunkhorst, as for many liberal institutionalists in international relations theory, the European Union is perceived to be important in lighting the way for the emergence of a global legal community (Brunkhorst, 2005, 163-176).

The potential of the European Union in extending solidarity and healing ancient enmities has been given significance by a number of social theorists who are nevertheless well aware of its democratic deficiencies and its bureaucratic mien. For Jürgen Habermas, whose remarks on the potential of the European Union to engender social solidarity are strongly reminiscent of Durkheim's appeals for social regulation (Habermas, 2001, 74-77), the EU opens the possibility of developing a post-national conception of citizenship cemented by a 'pay-off' in terms of social justice. It also presents the 
possibility of developing institutions that fulfil the normative promise of his work on communicative rationality. His discourse ethics presupposes the absolute individual freedom of people when making claims and reaching agreements, but also recognises that social consensus can only be formed with the empathy of each person in the situation for everyone, which is derived from solidarity' (Habermas, 1990, 247). Nancy Fraser adds to this a requirement that the concrete circumstances of 'dominated persons' must be taken into account so that the ways in which we interpret and communicate discourse is not the preserve of those who are from the privileged group who helped to create that discourse; she terms this 'an ethic of solidarity...from the standpoint of the collective concrete other' (Fraser, 1986, 425-429). It should be noted that Habermas is careful to distance himself from classical appeals to human essence, instead grounding his ethics in the 'postmetaphysical' realities of 'intersubjectively shared forms of life' (Habermas, 1990, 247). Likewise Fraser distances herself from an ethics of care, which also rests on essentialist assumptions.

One of the problems raised by the importance attached to constitutionalism by both Brunkhorst and Habermas is the remoteness of democratic and administrative institutions from the everyday concerns of citizens. How can the subjective feeling for solidarity connect with ideas for democratic renewal? Craig Calhoun notes two problems with adopting a 'purely political' conception of human beings; first, it misses out on the myriad forms of solidarity achieved outside political organisations, and second, it overestimates the mobilising potential of grand institutional ideas (Calhoun, 2002. 98). We can see both these problems in the general indifference to the democratic deficit within the EU and the legitimation problems exposed by the abortive attempt to launch a Constitution. So, while it undoubtedly true that democratic renewal is a prerequisite for the furtherance of solidarity, it is only distantly linked to the real world of solidaristic movements. Perhaps a 'step' is needed between the politics of competing interests and the goal of solidarity, and Ulrich Beck seems closer to the mark when he argues that the challenge of cosmopolitan Europe is to establish the reality of reconciliation (Beck, 
2006, 163-77), in which reconciliation prepares the ground for the future development of solidarity.

Axel Honneth offers a sophisticated inter-subjectivist analysis of solidarity in The Struggle for Recognition, in which he stresses the moral force inherent in the expectation of recognition at the levels of rights and societal solidarity. It is a moral feeling of indignation against various forms of disrespect that acts as an important motive force for members of movements in struggle. He complains that social science has tended to reduce motives for rebellion, protest and resistance to categories of 'interest', with the interests emerging out of objective inequalities in the distribution of opportunities (Honneth, 1996, 161). He is not suggesting that this basically utilitarian model is wrong, but that a fixation with 'interests' has obscured the significance of moral feelings (Honneth, 1996, 166). This raises the key question of what sort of moral claims may be justified. Honneth accepts that the significance of particular struggles has to be measured in terms of the positive or negative contribution that each makes to the realisation of 'undistorted forms of recognition' (Honneth, 1996, 170), which points to a strong link with Habermas's discourse ethics. Ultimately, solidarity is achieved when each individual understands that she or he is 'esteemed' by all citizens to the same degree. Solidarity is understood as 'an interactive relationship in which subjects mutually sympathise with their various different ways of life because, among themselves, they esteem each other symmetrically,' while societal solidarity is achieved when 'every member of a society is in a position to esteem himself or herself' (Honneth, 1996, 128-129). When speaking of people esteeming each other 'symmetrically' Honneth refers to a situation in which we view each other in the light of values that allow the abilities and traits of the other to appear significant for shared practice, thereby inspiring a genuine concern for the other person rather than simply exercising a passive tolerance. In this respect his normative perspective is shared by Alain Touraine, for whom the idea of 'living together' in the title of his book, Can We Live Together? transcends mere tolerance of 'the other' but invokes solidarity as the active support for the expression of multiple values and 
projects in a multicultural society by a new type of Subject (Touraine, 2000, 141).

The approaches discussed above share an unwillingness to dwell on an idea of a shared human nature and shared human needs which might supply criteria for judging which values, projects and movements are progressive and which are not. Richard Rorty is particularly vehement in opposing attempts to identify human solidarity with 'humanity as such', an identification which he derides as 'impossible...an awkward attempt to secularise the idea of being one with God' (Rorty, 1996, 198). However, when Contingency, Irony, and Solidarity appeared in 1983, his optimistic insistence that moral progress had taken place and was in the direction of greater human solidarity did much to revive academic interest in the concept (Rorty, 1996, 192). Rorty insists that our moral obligations to others derive from the fact that we share a tangible group identity, and that the appeal to specific identity will always be more effective than an appeal to our common humanity. So, he argues, if we want to elicit sympathy for the plight of young black city dwellers in the USA it is more persuasive, 'morally as well as politically', to describe them as our fellow Americans rather our fellow human beings (Rorty, 1996, 191). This privileging of nationality is highly contentious and difficult to square with the wider goal of human solidarity (Wilde, 2004b, 136-139). Rorty argues that greater solidarity is achieved when we learn more about unfamiliar people (description) and become more sensitive to their suffering, in the process learning more about ourselves (redescription) (Rorty, 1996, xvi). Rorty says that the task of promoting this enlightened consciousness is not the task of theory but one for the reporters and creative writers, and he emphasises the significant role that the novel can play. This is an important point, for the aesthetic dimension explores the subjective apprehension of social relationships, particularly in conflictual situations, in a way which often eludes the social scientific emphasis on structures and interests. ${ }^{3}$

Despite his antipathy to essentialism of all kinds, Rorty feels the need to fall back on something that does unite us as human being - 'recognition of a common susceptibility to humiliation is the only social bond that is needed' 
(Rorty, 1996, 91 - his emphasis). The 'essential' feeling which Rorty selects is both arbitrary and negative, but in making this move he opens up for theoretical consideration the issue he wants to suppress, the idea of a shared human nature, as Norman Geras has pointed out (Geras, 1995, 89-90). Ultimately Rorty is appealing to a shared human feeling that can serve to promote empathy and overcome indifference. The reluctance to embrace a humanistic ethics based on a normative conception of human nature has prevailed for decades in social science, and the problems it leaves become apparent when dealing with the idea of human solidarity. Honneth recognises that the claims made by various social groups in their struggles for recognition carry with them moral claims, but he has been reluctant (so far) to concede that it is difficult to judge the strengths of competing claims without an overarching humanist ethics (Wilde, 2004a). Touraine recognises the importance of renewing the political sphere by an infusion of ethics, but he has very little to say about the content of such an ethics (Wilde, 2007). In contrast, I suggest, contra Habermas, that there is something to be said about returning to classical notions of eudaemonia, renewed by psychoanalytical insights developed in the twentieth century, and Erich Fromm is the key figure here (Wilde, 2004b).

Fromm's humanistic ethics were first set out in Man For Himself, published in 1947. Linking his approach to the tradition of Aristotle and Spinoza, Fromm asks what it is that makes us human and concludes that selfawareness, reason and imagination have disrupted the harmony which characterises the existence of other animals. He argues that the emergence of reason "has created a dichotomy within man which forces him to strive everlastingly for new solutions' (Fromm, 2003, 28-29). The human being is both part of nature and yet is obliged always to transcend nature, and this tension is marked by what he terms 'existential dichotomies' - the knowledge of our certain death versus the richness of life, the awareness of the vast potentialities of humanity versus our individually limited capacities, our solitary uniqueness versus the fact that we cannot bear to be alone. In the light of these dichotomies we are thereby impelled to seek a new 'harmony', 
and this is where the ethics comes in. We can either choose regressive paths, such as blind submission to authority or tribalism of various sorts, or we choose the productive paths through the development of our inherent human potentialities, of which he specifies reason, love, and productive work (ibid, 32). If we choose the productive path it is possible for individuals to achieve fulfilment in a condition of 'relatedness to and solidarity with his fellow men' (ibid, p.9). A society which wishes to promote such solidarity should foster the productive potentials, and the aim of all social and political activities should be the unfolding and growth of every person (ibid, 171).

As a psychoanalyst, Fromm was clear that the cost for individuals in failing to realise the productive potentials was 'dysfunction and unhappiness', and that societies which suppress those potentials will suffer from a 'socially patterned defect' (ibid, 164-166). Although he supported a range of schemes and policies which might promote greater solidarity he did not do so in a systematic way. However, his work can be used to build a theoretical framework from which work could be conducted on how such potentials are realised and thwarted at a range of levels, from everyday life to the global, and how particular solidarities relate to the wider goal of human solidarity. 'Faith' also plays an important part in Fromm's social theory, not in a conventional religious sense but rather as an ineliminable aspect of human life which develops either progressively in the direction of faith in our own potential, the potential of others, and ultimately all humankind, or in the direction of irrational faith in such things as leaders, machines, or success (ibid., 148-157). The argument that faith is a necessary part of reason overcomes the modern sundering of the two, and the emphasis on productive faith opens up the possibility of dialogue between theistic and non-theistic ethical systems. Even though the divisiveness of religious affiliation has been and remains all too evident, there remains a shared ethical commitment to reciprocity embodied in the various expression of 'the Golden Rule' (Küng, 1997, 98-99), which, despite problems in its application (Appiah, 2006, 60-63) offers a basis for reconciliation between faiths, both theistic and secular. One of the strengths of Brunkhorst's book is the careful analysis of the 
development of the idea of brotherhood in the Judeo-Christian tradition, for it reveals a protracted struggle towards the idea of power in the people (Brunkhorst, 2005, 23-54). Stjernø, too, highlights the importance of specifically Christian ethics in the early and modern development of the idea of solidarity (Stjernø, 2004, 60-85, 287-326).

Today the idea of human solidarity has resurfaced in the emerging debates surrounding the idea of cosmopolitanism. Peter Waterman relates the social movements that have developed in response to globalisation to 'a complex solidarity for a complex globality' (Waterman, 2001, 235-239). He identifies six characteristics of solidarity - identity, substitution, complementarity, reciprocity, affinity, and restitution - each of which is needed if we are to move closer to international solidarity. However, each one taken in isolation can be problematic, perhaps reinforcing particularism or else not seriously engaging with the demands for thoroughgoing social change. Waterman is particularly concerned that international solidarity will not be achieved purely out of a sense of moral duty but rather as the rational expression of shared interest. However attractive this 'bottom up' approach to global solidarity, it begs the question of how far such solidarity can develop in a world in which the interests of powerful states prevail in a competitive interstate system. A more 'top down' perspective is offered in international relations theory by advocates of 'solidarism' (Dunne and Wheeler, 1999), which envisages states acting ultimately on behalf of all humanity to secure fundamental rights. However, even sympathetic writers such as Nicholas Wheeler and Alex Bellamy concede that it is not states but global civil society that is the principal agent promoting humanitarian values in global politics (Wheeler and Bellamy, 2005, 575-576). Interventions in Kosovo and Iraq dramatically highlight the difficulty of elucidating and implementing agreed principles on humanitarian interventions, and yet they also demonstrate the imperative of striving for new rules of conduct in international society (Linklater, 2005, 84-109).

Calhoun, as mentioned above, also links cosmopolitanism with solidarity, but argues that a transformation of public discourse is required if 
the goals of postnational democrats such as Habermas (2001) and Held (1995) to be achieved (Calhoun, 2002, 96-109). Calhoun is adamant that the cause of solidarity will not be advanced by merely adopting an 'attenuated' or 'soft' cosmopolitanism that is not prepared to challenge a capitalism driven by global neo-liberalism. In appealing for clarity in identifying the forces that oppose human solidarity Calhoun touches on the paradox referred to above. In the absence of a 'War of the Worlds' scenario, as Appiah characterises it (Appiah, 2006, 98), where is the external enemy that can stimulate the new solidarity? Clearly there are forces working against the advance of solidarity, but in terms of political confrontation these global economic elites have until recently proved elusive and shadowy, something that must clearly change if cosmopolitan solidarity is to develop (Sklair, 2002, 295-301). Waterman's complex model indicates that such solidarity cannot operate as did the spatially-bound, tightly organised solidarities of the past. Rather it would require more variegated forms, involving complex mediations and a rolling process of articulation and re-articulation. The pursuit of human solidarity would also require an explicit ethical movement, which is perhaps harder to envisage. Zygmunt Bauman, who has, at times, adopted a pessimistic tone about the ephemeral nature of contemporary social bonds, offers greater encouragement in the final chapter of Community, entitled "Many Cultures, One Humanity?" (Bauman, 2002, 124-143), in which he endorses the idea of a search for a common humanity. The 'solidarity of explorers' is achieved through individuals and groups going out in search of the best form of humanity, and bringing back the findings from their expeditions to a long dialogue in which all voices are heard and comparisons can be made. Bauman regards this is a true political process in which truly universal humanity accommodates the plurality of the forms of human life and makes pluralism serve the cause of humanity. There is, of course, an element of utopianism here, but one which is not disconnected from real possibilities for the development of human solidarity. 


\section{NOTES}

${ }^{1}$ In this respect the forthcoming book by Ray Pahl and Liz Spencer, Re-Thinking Friendship: Hidden Solidarities Today (Princeton: Princeton University Press) should make an important contribution. Pahl flags up the argument in an article in The New Statesman (2005).

2 Durkheim's account of solidarity has more radical implications than the limited reformism of the Solidarist movement (Stedman Jones, 2001, 94; Lukes, 1973, 172-178), but they share a broadly social liberal perspective.

${ }^{3}$ Crow quotes Michael Ignatief's view that painters and writers have generally evoked solidarity more successfully than social scientists, but (rightly) insists that the social scientist has a vital role to play in analysing the conditions in which greater solidarity can be achieved (Crow, 2002, 132). Giles Gunn explores the cultural expressions of human solidarity in the age of globalization in Beyond Solidarity (2001)

\section{BI BLI OGRAPHY}

Appiah, K. A. (2006), Cosmopolitanism: Ethics in a World of Strangers (London, Allen Lane Penguin).

Baker, J., Lynch, K., Cantillon, S. Walsh, J. (2004), Equality: From Theory to Action (Basingstoke, Palgrave)

Baldwin, P. (1990), The Politics of Social Solidarity: Class Bases of the European Welfare State, 1875-1975 (Cambridge, Cambridge University Press).

Bauman, Z. (2001), Work, Consumerism and the New Poor (Buckingham, Open University Press).

Bauman, Z. (2002), Community: Seeking Safety in an Insecure World (Cambridge, Polity)

Beck, U. (2006), The Cosmopolitan Vision (Cambridge, Polity).

Brunkhorst, H. (2005), Solidarity: From Civic Friendship To a Global Legal Community (Cambridge, Mass., MIT press).

Calhoun, C. (2002), "The Class Consciousness of Frequent Travellers:

Towards a Critique of Actually Existing Cosmopolitanism" in S. Vertovec and 
R. Cohen (eds), Conceiving Cosmopolitanism: Theory, Context, and Practice (Oxford, Oxford University Press).

Crow, G. (2002), Social Solidarities: Theories, Identities and Social Change (Buckingham, Open University Press).

Dunne, T. and Wheeler, N. J, (eds) (1999), Human Rights in Global Politics (Cambridge: Cambridge University Press).

Durkheim, E. (1964), The Division of Labour in Society (London, Collier Macmillan).

Etzioni, A. (ed) (1998), The Essential Communitarian Reader (Lanham, Maryland, Rowman and Littlefield)

Etzioni, A. (2004), The Common Good (Cambridge, Polity).

Fraser, N. (1986), "Toward a Discourse Ethic of Solidarity" in Praxis International, volume 5 (4).

Fromm, E. (2003), Man For Himself: An Inquiry into the Psychology of Ethics (London, Routledge)

Geras, N. (1995) Solidarity in the Conversation of Humankind: The Ungroundable Liberalism of Richard Rorty (London, Verso)

Gunn, G. (2001), Beyond Solidarity: Pragmatism and Difference in a Globalized World (Chicago, Chicago University Press).

Habermas, J. (1990), "J ustice and Solidarity" in Thomas Wren (ed) The Moral Domain: Essays in the Ongoing Discussion between Philosophy and the Social Science, pp. 224-253, (Cambridge, Mass., MIT press).

Habermas, J. (2001), The Postnational Constellation: Political Essays (Cambridge, Polity)

Halpern, D. (2005) Social Capital (Cambridge: Polity)

Hayward, J. E. S. (1959), "Solidarity: The Social History of An Idea in Nineteenth Century France" in International Review of Social History, volume 4, pp. 261-284.

Hayward, J. E. S. (1961), "The Official Social Philosophy of the French Third Republic: Léon Bourgeois and Solidarism" in International Review of Social History, volume 6, pp. 19-48). 
Held, D. (1995), Democracy and the Global Order: From the Modern State to Cosmopolitan Governance (Cambridge, Polity).

Honneth, A. (1996) The Struggle for Recognition: The Moral Grammar of Social Conflicts (Cambridge, Polity).

J essop, B. (2002), The Future of the Capitalist State (Cambridge, Polity).

Küng, H (1997), A Global Ethic for Global Politics and Economics (London, SCM Press).

Linklater, A, (2005), "The English School" in S. Burchill et al, Theories of International Relations (Basingstoke: Palgrave Macmillan).

Lukes, S. (1973), Emile Durkheim: His Life and Work (London, Allen Lane Penguin)

Magraw, R. (1992), "Socialism, Syndicalism and French Labour" in Dick Geary (ed), Labour and Socialist Movements in Europe Before 1914 (Oxford: Berg).

Mason, A (2000) Community, Solidarity and Belonging: Levels of Community and their Normative Significance (Cambridge, Cambridge University Press).

Melucci, A. (1989), Nomads of the Present: Social Movements and Individual Needs in Contemporary Society (London, Hutchinson)

Melucci, A. (1996), Challenging Codes: Collective Action in the Information Age (Cambridge, Cambridge University Press).

Pahl, R., (2005), "Hidden Solidarities That Span the Globe" in The New Statesman, 17 J aunary.

Putnam, R. (2001), Bowling Alone: The Collapse and Revival of American Community (Simon and Shuster).

Putnam, R. (ed) (2004), Democracies in Flux: The Evolution of Social Capital in Contemporary Society (New York, Oxford University Press).

Rorty, R. (1996) Contingency, Irony, and Solidarity (Cambridge: Cambridge University Press).

Sklair, L. (2001), The Transnational Capitalist Class (Oxford, Blackwell).

Stedman J ones, S. (2001), Durkheim Reconsidered (Cambridge: Polity).

Stjernø, S. (2004) Solidarity in Europe: The History of an Idea (Cambridge: Cambridge University Press). 
Touraine, A. (2000), Can We Live Together? Equality and Difference (Stanford, Ca., Stanford University Press).

Waterman, P. (2001), Globalization, Social Movements and the New Internationalisms (London, Continuum).

Wheeler, N. J., and Bellamy, A. J. (2005), "Humanitarian Intervention in World Politics" in J. Baylis and S. Smith (eds), The Globalization of World Politics, third edition, (Oxford: Oxford University Press).

Wilde, L. (1994), Modern European Socialism (Aldershot, Dartmouth).

Wilde, L. (2004a), "A 'Radical Humanist' Approach to the Concept of Solidarity" in Political Studies, volume 54 (1), pp. 162-178.

Wilde, L. (2004b), Erich Fromm and the Quest For Solidarity (New York, Palgrave).

Wilde, L. (2007), "The Ethical Challenge of Touraine's 'Living Together"' in The Journal of Global Ethics 3 (1), 2007. 